\title{
KAJIAN PENGARUH VARIASI PENAMBAHAN AIR ENTRAINING AGENT TERHADAP PARAMETER BETONMEMADAT MANDIRIDAN KUAT TEKAN BETON MUTU TINGGI
}

\author{
Simon Edward Hasiholan ${ }^{1)}$, Wibowo ${ }^{2}$, Sunarmasto ${ }^{3)}$ \\ 1)Mahasiswa Program Studi Teknik Sipil Fakultas Teknik Universitas Sebelas Maret \\ 2),3)Dosen Program Studi Teknik Sipil Fakultas Teknik Universitas Sebelas Maret \\ J1. Ir. Sutami No.36A, Jebres, Kota Surakarta, Jawa Tengah 57126 \\ Email : siahaan simon26@yahoo.com
}

\begin{abstract}
High strength concrete with technology in modern times is constantly being developed. In this case, the intended technology is a self-compacting concrete which in the process does not employ a vibrator. This study aims to determine the influence of the addition of Air Entraining Agent (AEA) on bigh strength concrete in obtaining self-compacting concrete according to EFNARC reference.

Tests conducted in this research are fresh concrete test such as slump-flow table, l-shape box, v-funnel and vfunnel T5minutes. In addition, there is a compressive strength test of 14 and 28 day concrete as well as testing of cement bonding time with the objective of knowing how much the initial and final tie time of cement is added to the Air Entraining Agent. This research uses experimental method conducted in the Materials Laboratory of Civil Engineering Study Program, Faculty of Engineering, Sebelas Maret University, Surakarta

This research results, concrete that only given the addition of Air Entraining Agent is classified as conventional concrete while the concrete with the addition of Superplasticizer which in this study as concrete is classified as self-compacting concrete and also the combination of addition of Air Entraining Agent with Superplasticizer belonging to the self-compacting concrete. Based on the research results obtained value of compressive strength of the average concrete with the addition of Air Entraining Agent compressive strength on the declining concrete. The decrease with the addition of Air Entraining Agent was 0,05\%, 0,1\%, and $0,15 \%$ of the reference concrete, the decrease of concrete compressive strength for age 14 was 14,46\%, $18,45 \%$, and $64,84 \%$ while for age 28 , concrete compressive strength is $9,91 \%, 15,32 \%$, and $44,82 \%$. The test results on fresh concrete values against the reference concrete, SA 4 (AEA 0,05\% + Superplasticizer 1,7\%) increased by $3 \%$ and $S A 5$ (AE A 0,10\% + Superplasticizer 1,7\%) increased by 5\% self-compacting concrete properties (SCC).
\end{abstract}

Key Words : Compressive Strength Of Concrete, High Strength Concrete, Self-Compacting Concrete, Air Entraining Agent

\begin{abstract}
ABSTRAK
Beton mutu tinggi dengan teknologi di zaman modern ini terus dikembangkan. Dalam hal ini, teknologi yang dimaksudkan ialah beton dengan kemampuan memadat mandiri yang dalam proses pengerjaannya tidak menggunakan alat penggetar. Penelitian ini bertujuan untuk mengetahui pengaruh penambahan Air Entraining Agent (AE $A$ )pada beton mutu tinggi dalam mendapatkan sifat memadat mandiri yang baik sesuai standar acuan EFNARC.

Pengujian yang dilakukan dalam penelitian ini berupa pengujian beton segar yaitu slump-flow table, l-shape box, v-funnel dan v-funnel $T_{5 \text { minutes. }}$ Selain itu dilakukan pengujian kuat tekan beton 14 dan 28 hari dan juga dilakukan pengujian waktu ikat semen dengan tujuan mengetahui berapa waktu ikat awal dan akhir dari semen apabila ditambahkan dengan Air Entraining Agent. Penelitian ini menggunakan metode ekperimental yang dilakukan di Laboratorium Bahan Program Studi Teknik Sipil Fakultas Teknik Universitas Sebelas Maret Surakarta
\end{abstract}

Penelitian ini dihasilkan, beton yang hanya diberi penambahan Air Entraining Agent saja tergolong beton konvensional sedangkan beton dengan penambahan Superplasticizer yang dalam penelitian ini sebagai beton acuan tergolong beton memadat mandiri dan juga 
kombinasi penambahan Air Entraining Agent dengan Superplasticizer tergolong beton memadat mandiri. Berdasarkan hasil penelitian didapatkan nilai kuat tekan rerata beton dengan adanya penambahan Air Entraining Agent kuat tekan pada beton menurun. Penurunan dengan penambahan Air Entraining Agent sebesar 0,05\%, 0,1\%, dan 0,15\% dari beton acuan, penurunan kuat tekan beton terjadi 14,46\%,18,45\%, dan 64,84\% pada umur beton 14 hari sedangkan untuk umur beton 28 , penurunan kuat tekan beton sebesar 9,91\%, 15,32\%, dan $44,82 \%$. Hasil pengujian terhadap nilai beton segar memadat mandiri terhadap beton acuan secara keseluruhan, SA 4 (AEA 0,05\% + Superplasticizer 1,7\%) menaikkan sebesar 3\% dan SA 5 (AEA $0,10 \%+$ Superplasticizer 1,7\%) menaikkan sebesar 5\% sifat beton memadat mandiri (SCC).

Kata Kunci : Kuat Tekan Beton, Beton Mutu Tinggi, Beton Memadat Mandiri, Air Entraining Agent

\section{Pendahuluan}

Penggunaan material beton sangat banyak digunakan dibandingkan dengan material lain yang sama fungsinya sebagai penyusun sebuah konstruksi bangunan seperti halnya baja dan kayu. Dengan berbagai kelebihan yang dimilikinya beton menjadi bahan terdepan yang digunakan masyarakat dalam membuat sebuah kontruksi bangunan. Segi ekonomis dan mudah dalam pengerjaanya menjadi faktor yang mendasar mengapa beton menjadi pilihan masyarakat. Dengan perkembangan zaman kearah modern pembuatan beton diharapkan dapat memadat mandiri atau yang dikenal dengan Self Compacting Concrete (SCC). Dengan beton memadat mandiri, penggunaan alat pemadat atau vibrator dapat dikurangkan. Beton memadat mandiri atau Self Compacting Concrete (SCC) adalah beton yang dapat mengalir diakibatkan oleh beratnya sendiri dan tidak memerlukan alat bantu untuk pemadatan. Berikut ini adalah syarat untuk mendapatkan beton SCC menurut EFNARC, yaitu:

a. Filling-ability, kemampuan dari campuran beton segar untuk dapat mengisi ruangan tanpa vibrasi.

b. Passing-ability, kemampuan dari campuran beton segar untuk dapat melewati tulangan.

c. Segregation resistance, campuran beton yang tidak mengalami segregasi.

Dengan demikian, penelitian ini bertujuan untuk mendapatkan nilai parameter beton SCC menurut EFNARC "Self Compacting" dari The European Guidelines for SCC, 2002 dan "Self Compacting" dari The European Guidelines for SCC, 2005 dan kuat tekan beton pada umur 14 hari dan 28 hari dari beton yang menggunakan bahan tambah air entraining agent kadar 0,05\%, $0,1 \%$ dan $0,15 \%$ dan kombinasi air entraining agent kadar $0,05 \%, 0,1 \%$ dan $0,15 \%$ dengan Superplasticizer dengan kadar 1,7\% dari berat semen. Penelitian ini menggunakan air entraining agent dengan nama pabrik Sika AER berdasarkan SNI 2496 tahun 2008. Penentuan kadar variasi berdasarkan product data sheet yang dikeluarkan oleh PT. Sika Indonesia dengan pertimbangan bahan material yang dipergunakan pada penelitian ini.

\section{Tinjauan Pustaka}

Perkembangan teknologi konstruksi sangat pesat. Pada awalnya beton jenis memadat mandiri atau beton SCC ini dikembangkan di jepang pada tahun 1990-an sebagai solusi dalam gedung yang memiliki nilai artistik dengan bentuk yang rumit sehingga tidak memungkinkan apabila proses pengecoran menggunakan beton normal.

\section{Air Entraining Admixture (AEA)}

Air entraining admixture adalah bahan tambah campuran beton berupa surfaktan yang dapat menciptakan gelembung-gelembung udara yang sangat halus dengan diameter $1 / 100 \mathrm{~mm}$ $2 \mathrm{~mm}$, yang dapat memperbaiki sifat workability karena gelembung udara berfungsi sebagai minyak pelumas. 


\section{Pengaruh-Pengaruh Air Entraining Admixture (AEA) Terhadap Sifat-Sifat Beton}

Berikut ini adalah pengaruh penggunaan Air Entraining Admixture (AEA) terhadap sifat-sifat beton:

\section{Kuat Tekan Beton}

Penggunaan AEA dapat meningkatkan kelecekan dan kemudahan pengerjaan (workability) disisi lain penggunaan AEA dapat mengurangi kuat tekan beton.

Workability Beton (Kemudahan Pengerjaan)

Dengan menggunakan AEA dapat meningkatkan nilai slump test pada beton yang bertujuan untuk memudahkan pekerjaan yang dilakukan pada beton tersebut.

Pengikatan Waktu

Penggunaan AEA tidak berpengaruh pada waktu pengikatan antar material campuran beton.

Bleeding

Dengan menggunakan AEA dapat mengurangi terjadinya bleeding dalam campuran beton.

Perubahan Volume

Penggunaan AEA tidak menyebabkan beton mengalami susut volume.

Kohesif

AEA dapat meningkatkan sifat kohesif beton.

Densitas Beton

Penggunaan AEA dapat mengurangi berat jenis beton tersebut hingga penurunan densitas $500 \mathrm{~kg} / \mathrm{m}^{3}$

Keawetan beton (durability)

Pada umumnya penggunaan AEA dapat meningkatkan keawetan beton karena sifat permeable beton berkurang oleh karenanya dan juga dapat meningkatkan ketahanan terhadap pembekuan dan pencairan.

\section{Metode Penelitian}

Tinjauan Umum

Penelitian ini diperuntukan untuk mengetahui pengaruh penggunaan air entraining agent terhadap parameter beton mutu tinggi memadat mandiri (High Strength Self Compacted Concrete HS-SCC). Penelitian ini dilaksanakan di Laboratorium Bahan dan Struktur Program Studi Teknik Sipil Universitas Sebelas Maret Surakarta (UNS). Penentuan kadar penggunaan SikaAER berdasarkan product data sheet yang dikeluarkan oleh PT. Sika Indonesia dengan pertimbangan bahan material yang dipergunakan pada penelitian ini. Sampel tersebut akan diuji sifat beton segar SCC yaitu filling-ability, passing-ability, segregation resistance. Selain itu kuat tekan 42 sampel akan diuji pada umur 14 hari dan 28 hari menggunakan Compression Testing Macbine (CTM). 


\section{Benda Uji}

Penelitian ini menggunakan cetakan (mould) benda uji berbentuk tabung dengan ukuran diameter $15 \mathrm{~cm}$ dan tinggi $30 \mathrm{~cm}$. Berikut ini adalah penamaan dari sampel tersebut:

Tabel 1 Penamaan dan Jumlah Benda Uji

\begin{tabular}{|c|c|c|c|c|c|c|}
\hline \multirow[b]{2}{*}{ No } & \multirow[b]{2}{*}{ Campuran Beton } & \multicolumn{2}{|c|}{ Kadar } & \multirow[b]{2}{*}{ Kode } & \multicolumn{2}{|c|}{ Jumlah } \\
\hline & & Superplasticizer & $\begin{array}{l}\text { Sika } \\
\text { AER }\end{array}$ & & 14 hari & 28 hari \\
\hline 1 & Superplasticizer & $1,70 \%$ & - & $\mathrm{BA}$ & 3 & 3 \\
\hline 2 & Sika AER & - & $0,05 \%$ & SA 1 & 3 & 3 \\
\hline 3 & Sika AER & - & $0,10 \%$ & SA 2 & 3 & 3 \\
\hline 4 & Sika AER & - & $0,15 \%$ & SA 3 & 3 & 3 \\
\hline 5 & Superplasticizer + Sika AER & $1,70 \%$ & $0,05 \%$ & SA 4 & 3 & 3 \\
\hline 6 & Superplasticizer + Sika AER & $1,70 \%$ & $0,10 \%$ & SA 5 & 3 & 3 \\
\hline 7 & Superplasticizer + Sika AER & $1,70 \%$ & $0,15 \%$ & SA 6 & 3 & 3 \\
\hline
\end{tabular}

\section{Tahap Penelitian}

Tahap penelitian yang dilakukan ialah:

\section{a. Tahap I}

Mempelajari studi literatur mengenai beton mutu tinggi dan beton memadat mandiri (SelfCompacting Concrete).

b. Tahap II

Menyiapkan alat dan bahan yang akan digunakan.

c. Tahap III

Pengujian kualitas bahan material yang akan digunakan sebagai acuan apakah material yang digunakan sudah memenuhi standar yang berlaku.

d. Tahap IV

Melakukan penghitungan campuran beton (mix design high strength self compacting concrete).

e. Tahap V

Penambahan air entraining agent serta superplasticizer yang digunakan dan pada tahap ini juga dilaksanakan pencampuran beton (mixing concrete) dengan menggunakan mixer yang berada di laboratorium.

\section{f. Tahap VI}

Melakukan pengujian beton segar dengan syarat Self-Compacting Concrete EFNARC, 2005. Pengujian yang dilakukan adalah Slump-Flow by Abrams Cone, $T_{50 c m}$ Slump-Flow L-shape Box Test, $V$-funnel, $V$-funnel at $T_{5 \text { minutes }}$

g. Tahap VII

Melakukan perawatan beton dengan memasukkan ke dalam bak curing.

h. Tahap VIII

Melakukan pengujian kuat tekan beton pada umur 14 hari dan 28 hari menggunakan Compression Testing Machine (CTM)

\section{i. Tahap IX}

Melakukan analisis data dari hasil pengujian untuk mendapatkan kesimpulan hubungan antara variabel-variabel yang sedang diteliti.

j. Tahap X

Membuat kesimpulan dan saran mengenai data yang dianalisis. 
Analisis Data dan Pembahasan

Hasil Pengujian Bahan Penyusun Beton

a. Pengujian Agregat Halus

Tabel 2 Rekapitulasi Pengujian Agregat Halus

Jenis Penguijan Hasil Pengujian

\begin{tabular}{llll}
\hline Bulk Specific Gravity & 2,45 & - & - \\
\hline Bulk Specific Gravity SSD & 2,51 & $2,5-2,7$ & Memenuhi Syarat \\
\hline Apparent & 2,60 & - & - \\
\hline Absorbsion & 2,27 & - & - \\
\hline Kandungan Lumpur & $1 \%$ & Maksimum 5\% & Memenuhi Syarat \\
\hline Kandungan Zat Organik & Kuning Muda & Jernih atau Kuning Muda & Memenuhi Syarat \\
\hline Modulus Kehalusan & 2,52 & $1,5-3,8$ & Memenuhi Syarat \\
\hline
\end{tabular}

b. Pengujian Agregat Kasar

Tabel 3 Rekapitulasi Pengujian Agregat Kasar

\begin{tabular}{llll}
\multicolumn{1}{c}{ Jenis Pengujian } & Hasil Pengujian & \multicolumn{1}{c}{ Syarat } & \multicolumn{1}{c}{ Keterangan } \\
\hline Bulk Specific Gravity & 2,58 & - & - \\
\hline Bulk Specific Gravity SSD & 2,61 & $2,5-2,7$ & Memenuhi Syarat \\
\hline Apparent & 2,65 & - & - \\
\hline Absorbsion & 1,01 & - & - \\
\hline Abrasi & 30,88 & $<50 \%$ & Memenuhi Syarat \\
\hline Gradasi & 5,96 & $5-8$ & Memenuhi Syarat \\
\hline
\end{tabular}

c. Rancang Campur

Berdasarkan hasil perhitungan rancang campur dengan bahan material di atas, sehingga didapatkan sebagai berikut:

Tabel 4 Rekapitulasi Kebutuhan Material

\begin{tabular}{|c|c|c|c|c|c|c|c|c|c|c|}
\hline \multirow[b]{2}{*}{ No } & \multirow[b]{2}{*}{ Campuran Beton } & \multicolumn{2}{|c|}{ Kadar } & \multirow[b]{2}{*}{ Kode } & \multicolumn{6}{|c|}{ Material } \\
\hline & & Superplasticizer & Sika AER & & $\begin{array}{l}\text { Semen } \\
\left(\mathrm{Kg} / \mathrm{m}^{3}\right)\end{array}$ & $\begin{array}{l}\text { Agregat } \\
\text { Kasar } \\
\left(\mathrm{Kg} / \mathrm{m}^{3}\right)\end{array}$ & $\begin{array}{l}\text { Agregat } \\
\text { Halus } \\
\left(\mathrm{Kg} / \mathrm{m}^{3}\right)\end{array}$ & Air $\left(\right.$ liter $\left./ \mathrm{m}^{3}\right)$ & $\begin{array}{c}\text { Superplasticizer } \\
\quad\left(\text { liter } / \mathrm{m}^{3}\right)\end{array}$ & $\begin{array}{c}\text { Sika AER } \\
\left(\text { liter } / \mathrm{m}^{3}\right)\end{array}$ \\
\hline 1 & Superplasticizer & $1,70 \%$ & - & $\mathrm{BA}$ & 696,03 & 784,77 & 703,528 & 187,93 & 11,11 & - \\
\hline 2 & Sika AER & - & $0,05 \%$ & SA 1 & 714,34 & 784,77 & 703,53 & 192,87 & - & 0,35 \\
\hline 3 & Sika AER & - & $0,10 \%$ & SA2 & 713,74 & 784,77 & 703,53 & 192,71 & - & 0,71 \\
\hline 4 & Sika AER & - & $0,15 \%$ & SA 3 & 713,14 & 784,77 & 703,53 & 192,55 & - & 1,06 \\
\hline 5 & Superplasticizer + Sika AER & $1,70 \%$ & $0,05 \%$ & SA 4 & 695,46 & 784,77 & 703,53 & 187,77 & 11,1 & 0,35 \\
\hline 6 & Superplasticizer + Sika AER & $1,70 \%$ & $0,10 \%$ & SA 5 & 694,88 & 784,77 & 703,53 & 187,62 & 11,09 & 0,69 \\
\hline 7 & Superplasticizer + Sika AER & $1,70 \%$ & $0,15 \%$ & SA 6 & 694,32 & 784,77 & 703,53 & 187,47 & 11,08 & 1,03 \\
\hline
\end{tabular}

\section{Hasil dan Analisa Pengujian Beton}

Pengujian Waktu Ikat (Setting Time)

Pengujian ini dilakukan untuk mengetahui pengaruh waktu ikat awal dan waktu ikat akhir dari bahan tambah Sika AER terhadap beton memadat mandiri.

Berdasarkan hasil penelitian penggunaan Sika AER tidak mempengaruhi waktu ikat akhir beton. Sesuai dengan sifat dari Sika AER, Sika AER memiliki massa jenis yang sama dengan air yaitu $1.01 \mathrm{~kg} / \mathrm{L}$ sehingga penambahan Sika AER tidak berbeda dengan penambahan air pada proses pengikatan dengan semen. 


\section{Waktu Ikat}

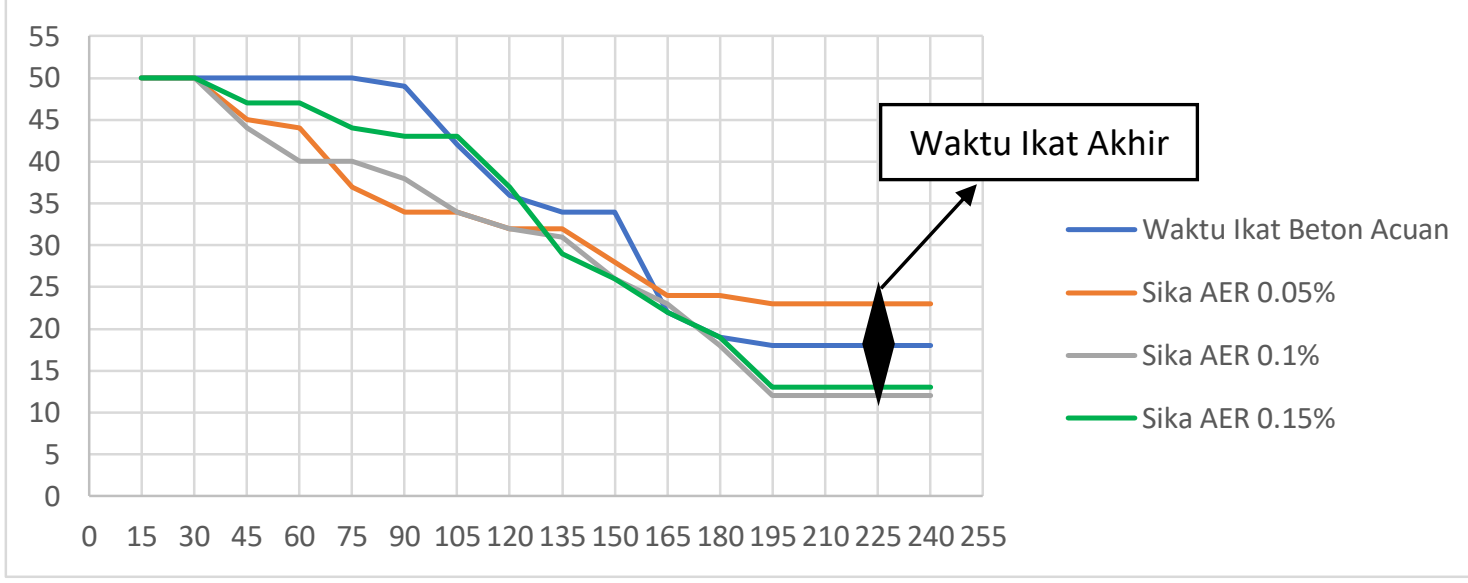

Gambar 1 Grafik Kedalaman Penetrasi (mm) Terhadap Waktu ikat Beton (menit)

\section{Hasil Tes Beton Segar}

Pengujian beton segar untuk mendapatkan penilaian filling ability, passing ability, dan segregation resistance. Berikut ini adalah hasil pengujian beton segar:

\section{a. Filling Ability}

Beton dengan kombinasi air entraining agent (AEA) dan superplasticizer dapat dilakukan pengujian beton segar (SCC) sedangkan beton yang hanya ditambah air entraining agent saja tidak dapat dilakukan karena adukan beton tidak dapat mengalir sehingga dapat dikategorikan sebagai beton konvensional dan pengujian terhadap parameter memadat mandiri tidak dilakukan. Perilaku beton dengan kombinasi air entraining agent dan superplasticizer memiliki penilaian yang baik terhadap kriteria beton segar menurut EFNARC 2002. Pada saat penambahan kadar AEA 0,15\% kombinasi dengan Superplasticizer 1,7\% terjadi penurunan kualitas dari beton memadat mandiri, hal ini dikarenakan kadar yang digunakan pada zat tambah lain yaitu Superplasticizer yang berfungsi sebagai pengurang penggunaan air atau chemical admixture tipe F yaitu Water Reducing and High Range Admixture yang menyebabkan berkurangnya kinerja dari gelembung udara sebagai pelumas beton untuk meningkatkan kelecakan dari beton tersebut. Hasil pengujian $T_{50 \mathrm{~cm}}$ slump flow beton acuan tidak memenuhi syarat penilaian EFNARC 2002. Menurut EFNARC 2002, syarat waktu yang dibutuhkan untuk mencapai diameter sebaran $50 \mathrm{~cm}$ berkisar antara 2-5 detik sedangkan pada beton acuan memerlukan waktu 5.64 detik, disisi lain beton SA 4 dan SA 5 memenuhi syarat tersebut. Hasil pengujian $V$-funnel untuk filling ability, beton segar dengan kode BA, SA 4 SA 5 dan SA 6 memenuhi kriteria menurut EFNARC 2002 dengan syarat waktu pengujian $V$ funnel berkisar antara 6-12 detik

\section{b. Passing Ability}

Pengujian beton segar terhadap penilaian passing ability ditujukan untuk mengetahui apakah adukan beton dapat melewati tulangan dengan baik. Dari pengujian ini didapatkan nilai blocking ratio. Menurut EFNARC 2002 nilai blocking ratio berkisar antara 0,8-1. Berdasarkan hasil pengujian beton acuan dan beton yang dikombinasikan penambahan superplasticizer dan $A E A$ memiliki nilai blocking ratio maksimum yang berarti sifat gelembung udara yang dihasilkan $A E A$ dapat membantu melewati tulangan dengan baik sehingga memenuhi kriteria beton segar (SCC) menurut EFNARC 2002. 


\section{c. Segregation Resistance}

Hasil pengujian beton segar yang tahan terhadap segregasi ialah beton dengan kode SA 5 yang merupakan kombinasi dari 0,1\% AE $A+1,7 \%$ Superplasticizer. Menurut EFNARC 2002, beton segar yang termasuk dalam beton SCC harus memiliki nilai $V$-funnel at T5minutes berkisar antara 0-3 detik. Dalam hal ini fungsi dari gelembung udara yang dihasilkan oleh $A E A$ dengan kadar $0,1 \%$ dalam campuran $0,1 \% A E A+1,7 \%$ Superplasticizer dapat menjaga homogenitas adukan beton.

\section{Kuat Tekan Beton}

Pengujian ini dilakukan untuk mengetahui kuat tekan dari beton dalam masing-masing komposisi, serta digunakan untuk mengetahui pengaruh penambahan Air Entraining Agent maupunpenambahan Air Entraining Agent dikombinasikandengan penambahan Superplasticizer dalam kaitannya dengan kuat tekan beton mutu tinggi.

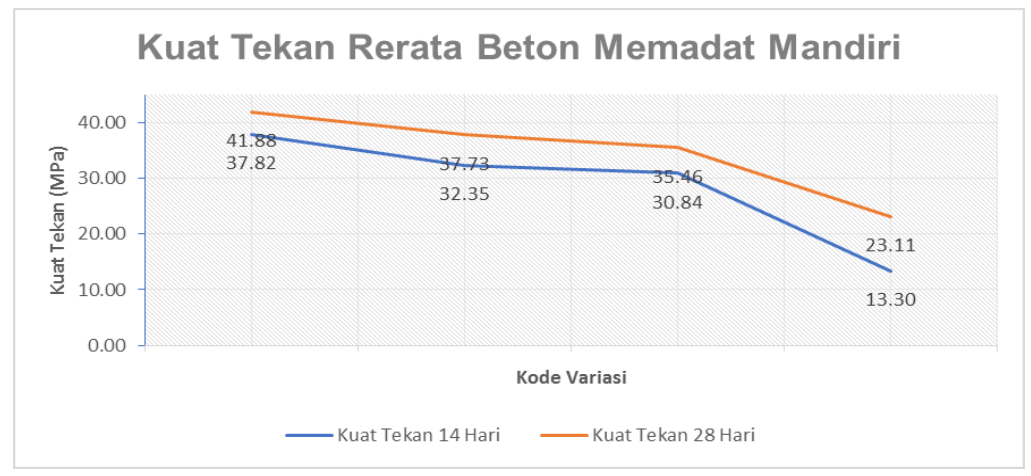

Gambar 2 Hasil Kuat Tekan Rerata Beton Memadat Mandiri

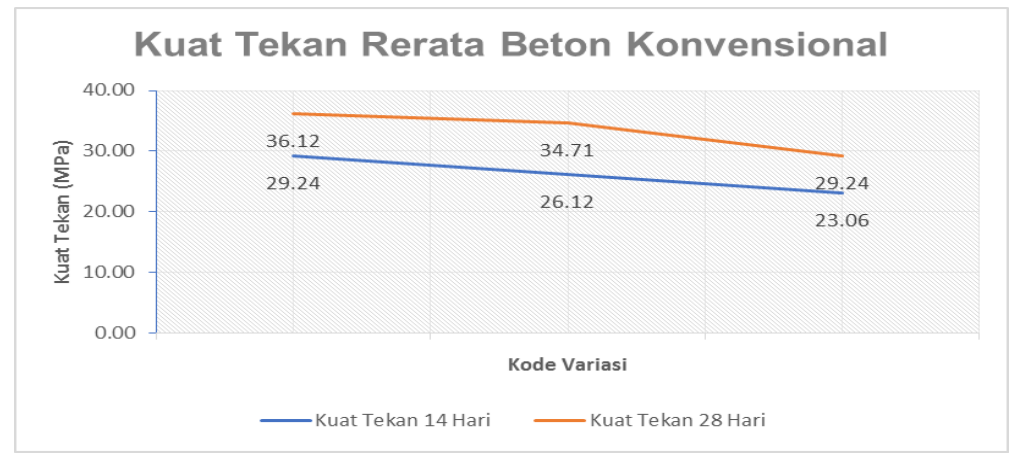

Gambar 3 Hasil Kuat Tekan Rerata Beton Konvensional

Gambar 2 dan 3 menunjukkan hasil kuat tekan benda uji. Grafik tersebut terbagi menjadi dua yaitu grafik kuat tekan beton memadat mandiri dan beton konvensional. Hal ini didasari dari perilaku beton dengan kode variasi SA 1, SA 2 dan SA 3 tidak dapat dilakukan pengujian parameter beton memadat mandiri dikarenakan tidak dapat mengalir sehingga beton dengan kode variasi SA 1, SA 2 dan SA 3 tergolong beton konvensional. Kedua grafik di atas dapat disimpulkan bahwa dengan penambahan Air Entraining Agent (AEA) dapat menurunkan kuat tekan beton. Semakin bertambahnya kadar $A E A$ menghasilkan gelembung udara yang semakin banyak sehingga menyebabkan beton menjadi lebih rapuh. 


\section{Analisis Regresi Kombinasi AEA + Superplasticizer terhadap Beton Acuan}

\section{(Superplasticizer)}

Dalam subbab ini akan dibahas seberapa jauh faktor penambahan kadar $A E A$ terhadap beton acuan yang mempengaruhi kuat tekan beton pada umur 14 dan 28 hari:

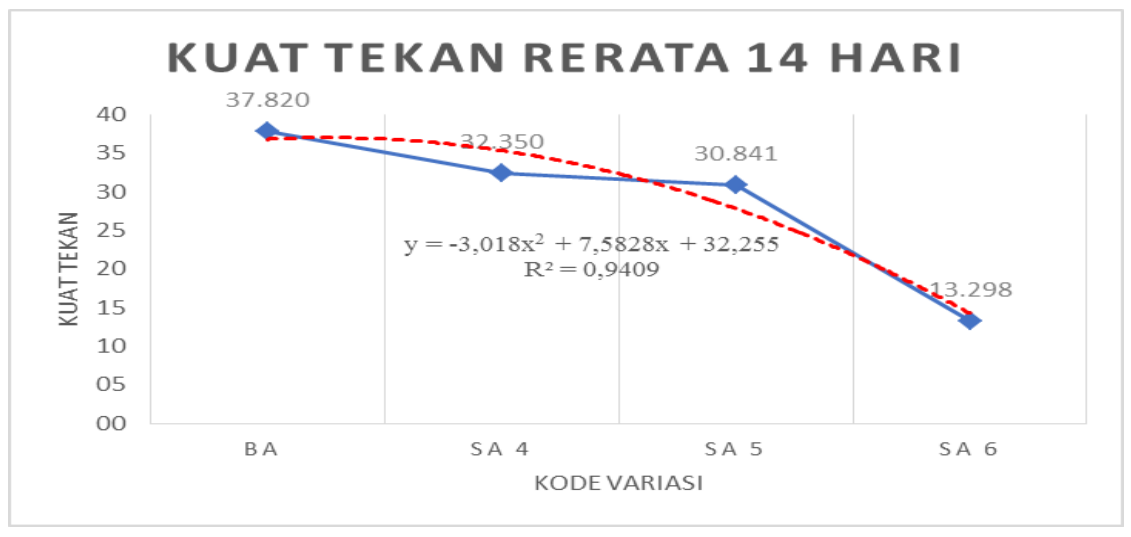

Gambar 4 Analisis Regresi Kuat Tekan Rerata Beton Memadat Mandiri Umur 14 Hari

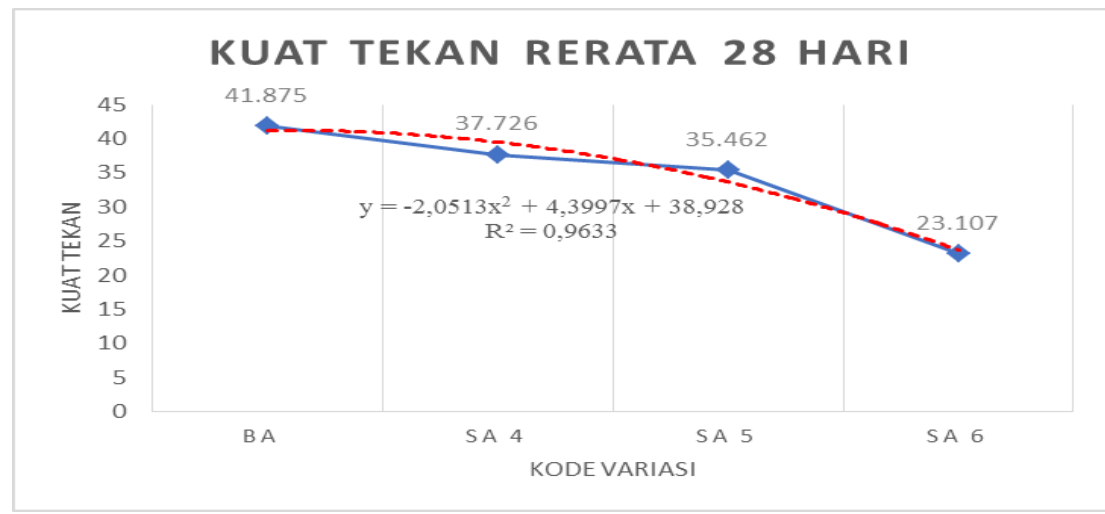

Gambar 5 Analisis Regresi Kuat Tekan Rerata Beton Memadat Mandiri Umur 28 Hari

Berdasarkan gambar 4 dan 5 dapat disimpulkan semakin bertambahnya kadar $A E A$ dalam beton menyebabkan kuat tekan menurun. Semakin banyaknya kadar dari $A E A$ jumlah rongga udara (air void) semakin banyak yang menyebabkan beton menjadi rapuh sehingga kuat tekannya menurun. Kuat tekan rerata beton 14 hari memiliki koefisien y $=-3,018 \times 2+$ $7,5828 \mathrm{x}+32,255$ dan koefisien determinasi $\mathrm{R}^{2}=0,94$. Kuat tekan rerata beton 28 hari memiliki koefisien $\mathrm{y}=-2,0513 \mathrm{x} 2+4,3997 \mathrm{x}+38,928$ dan koefisien determinasi $\mathrm{R}^{2}=0,96$.

\section{SIMPULAN DAN SARAN}

\section{Simpulan}

Dari data hasil pengujian, analisis data dan pembahasan dapat diambil beberapa kesimpulan sebagai berikut:

1. Penggunaan Air Entraining Agent (AEA) dapat memperbaiki sifat dari beton memadat mandiri, dalam penelitian ini untuk hasil pengujian terhadap nilai beton segar memadat mandiri terhadap beton acuan secara keseluruhan, SA 4 (AEA 0,05\% + Superplasticizer $1,7 \%$ ) menaikkan sebesar 3\% dan SA 5 (AEA 0,10\% + Superplasticizer 1,7\%) menaikkan sebesar $5 \%$ sifat beton memadat mandiri (SCC).

2. Pengaruh Air Entraining Agent terhadap kuat tekan rerata beton, menyebabkan kuat tekan pada beton menurun. Penurunan dengan penambahan Air Entraining Agent sebesar $0,05 \%, 0,1 \%$, dan $0,15 \%$ dari beton acuan, penurunan kuat tekan beton terjadi $14,46 \%$, 
18,45\%, dan 64,84\% pada umur beton 14 hari sedangkan untuk umur beton 28 , penurunan kuat tekan beton sebesar 9,91\%, 15,32\%, dan 44,82\%.

3. Penambahan $A E A$ tidak cocok untuk sebagai zat tambah beton mutu tinggi, dikarenakan rongga yang ditimbulkan dari AEA mengurangi kekuatan beton tersebut.

4. Nilai kuat tekan rata-rata beton pada umur 14 hari dengan kode BA (Superplasticizer 1,7\%), SA 1 (AEA 0,05\%), SA 2 (AEA 0,10\%), SA3 (AEA 0,15\%), SA 4 (AEA $0,05 \%+$ Superplasticizer 1,7\%), SA 5 (AEA 0,10\%+ Superplasticizer 1,7\%), SA 6 (AEA 0,15\%+ Superplasticizer 1,7\%) adalah 37,82 MPa, 29,24 MPa, 26,12 MPa, 23,06 MPa, 32,35 MPa, $30,84 \mathrm{MPa}, 13,30 \mathrm{MPa}$. Nilai kuat tekan rata-rata beton pada umur 28 hari dengan kode BA (Superplasticizer 1,7\%), SA 1 (AEA 0,05\%), SA 2 (AEA 0,10\%), SA3 (AEA 0,15\%), SA 4 (AEA 0,05\%+ Superplasticizer 1,7\%), SA 5 (AEA 0,10\%+ Superplasticizer 1,7\%), SA 6 (AEA 0,15\%+Superplasticizer 1,7\%) adalah 41,88 MPa, 36,12 MPa, 34,71 MPa, 29,24 $\mathrm{MPa}, 37,73 \mathrm{MPa}, 35,46 \mathrm{MPa}, 23,11 \mathrm{MPa}$.

5. Berdasarkan hasil pengujian beton, beton yang hanya diberi penambahan $A E A$ saja yaitu SA 1 ( $A E A 0,05 \%)$, SA 2 (AEA 0,10\%), danSA3 (AEA 0,15\%) dapat dikategorikan sebagai beton konvensional.

\section{Saran}

Berikut ini adalah saran yang dapat penulis berikan sehubungan dengan penelitian ini:

1. Jenis dan persentase penggunaan kadar Superplasticizer perlu dipertimbangkan lebih lagi sebagai zat tambah selain $A E A$ dalam campuran beton, agar fungsi dari $A E A$ dapat maksimal.

2. Perlunya zat tambah mineral (Mineral Admixture) yang berfungsi sebagai filler untuk mengisi ruang kosong pada campuran beton dalam mengantisipasi penurunan kuat tekan beton akibat penambahan $A E A$.

3. Perlunya penambahan benda uji untuk antisipasi hal yang tidak diinginkan selama proses penelitian.

4. Pengujian kuat tekan untuk umur 56 hari dan 90 hari, untuk mengetahui faktor umur dalam penggunaan $A E A$.

5. Penelitian selanjutnya diharapkan dapat menjelaskan analisis persebaran gelembung udara yang dihasilkan oleh $A E A$.

\section{Referensi}

Anonim. 1971. Peraturan Beton Indonesia (PBI 1971). Departemen Pekerjaan Umum, Jakarta.

Anonim. 1990. Tata Cara Rencana Pembuatan Campuran Beton Normal. SK SNI T-15-1990-03. Depertemen Pekerjaan Umum.Bandung

Anonim. 2008. Spesifikasi Bahan Tambah Pembentuk Gelembung Udara Untuk Beton.SNI2496-2008.Badan Standardisasi Nasional. Bandung

Anonim. Specification for Chemical Admixtures for Concrete. ASTM C.494

Beata Laz'niewska-Piekarczyk. 2012. The type of air-entraining and viscosity modifying admixtures and porosity and frost durability of high performance self-compacting concrete. Elsevier.Ltd

David, S. 2011. Pengaruh Pemakaian Portland Composite Cement (PCC) Terhadap Ketahanan Sulfat Pada Self Compacting Concrete (SCC). Universitas Indonesia

H.K. Kim, J.H. Jeon, dan H.K. Lee. 2011. Workability, and mechanical, acoustic and thermal properties of lightweight aggregate concrete with a high volume of entrained air. Elsevier.Ltd 
Marchin, A. 2012. Studi Kuat Tekan Beton Normal Mutu Sedang Dengan Campuran Abu Sekam Padi $(R H A)$ Dan Limbah Adukan Beton (CSW). Universitas Indonesia

Tjokrodimulyo, K. Teknologi Beton. Naftiri. 1996. Yogyakarta 